INSIDE OUT, OUTSIDE IN 
Also by Robert Gregg

SPARKS FROM THE ANVIL OF OPPRESSION: Philadelphia's African Methodists and Southern Migrants, 1890-1940 


\section{Inside Out, Outside In}

\section{Essays in Comparative History}

\section{Robert Gregg}

Assistant Professor

The Richard Stockton College of New Jersey 


\section{MACMILLAN PRESS LTD}

Houndmills, Basingstoke, Hampshire RG21 6XS and London

Companies and representatives throughout the world

A catalogue record for this book is available from the British Library.

ISBN 978-1-349-40989-1

ISBN 978-0-230-51039-5 (eBook)

DOI $10.1057 / 9780230510395$

First published in the United States of America 2000 by

ST. MARTIN'S PRESS, INC.,

Scholarly and Reference Division,

175 Fifth Avenue, New York, N.Y. 10010

Library of Congress Cataloging-in-Publication Data

Gregg. Robert, 1958-

Inside out, outside in : essays in comparative history / Robert

Gregg.

p. $\mathrm{cm}$.

Includes bibliographical references and index.

1. United States-History. 2. South Africa-History. 3. Great

Britain-History. 4. India-History-British occupation,

1765-1947. I. Title.

E179.G82 1999

$900-\mathrm{dc} 21$

$98-46681$

CIP

Robert Gregg 2000

Softcover reprint of the hardcover 1st edition 2000 978-0-333-74115-3

All rights reserved. No reproduction, copy or transmission of this publication may be made without written permission.

No paragraph of this publication may be reproduced, copied or transmitted save with written permission or in accordance with the provisions of the Copyright, Designs and Patents Act 1988, or under the terms of any licence permitting limited copying issued by the Copyright Licensing Agency, 90) Tottenham Court Road, London WIP 9HE.

Any person who does any unauthorised act in relation to this publication may be liable to criminal prosecution and civil claims for damages.

The author has asserted his right to be identified as the author of this work in accordance with the Copyright, Designs and Patents Act 1988.

This book is printed on paper suitable for recycling and made from fully managed and sustained forest sources.

$\begin{array}{llllllllll}10 & 9 & 8 & 7 & 6 & 5 & 4 & 3 & 2 & 1\end{array}$

$\begin{array}{llllllllll}09 & 08 & 07 & 06 & 05 & 04 & 03 & 02 & 01 & 00\end{array}$ 


\section{To Owen Dudley Edwards}


This page intentionally left blank 


\section{Contents}

Preface ix

1 Apropos Exceptionalism: Imperial Location and 1

Comparative Histories of South Africa and the United States

Comparatively Speaking 5

After the Gold Rush 9

Omaha, Somewhere in Middle America $\quad 18$

Conclusion $\quad 25$

2 Homelands, Harlem and Comparative History 27

3 Beyond Nation. Beyond Methodism? 33

4 The Empire and Mr. Thompson: The Making of 39

Indian Princes and the English Working Class with Madhavi Kale

Prologue $\quad 39$

All About R. Tagore $\quad 41$

The Other Side of History $\quad 47$

Rallying Metcalfe $\quad 57$

Indian Princes Meet the English Working Class $\quad 61$

$\begin{array}{ll}\text { Epilogue } & 79\end{array}$

5 Piper at the Gates of Dawn 81

6 Beyond Boundaries, Beyond the Whale 88

7 Beyond Silly Mid-Off: C. L. R. James, Ranjitsinhji 96 and the Boundaries of Englishness

$\begin{array}{lr}\text { The Protestant Ethic and the Spirit of Cricket } & 97 \\ \text { Sting without Stingo } & 103\end{array}$

The Making of an Englishman $\quad 111$

Fielding Silly Mid-Off Again 117

Epilogue: Tensions of Being an Umpire 121

8 The Sound of Silence 124

9 A Common Wind 127 
10 Class, Culture and Empire: Making Social History 132 Prologue: Can the 'Subaltern' Write History? 132

My Dinner with André 136

Of Mr. Edward P. Thompson ... 141

... and Others $\quad 149$

Exceptionalism Revisited 153

Epilogue: Can the 'Organization Man' 155

Write History?

$\begin{array}{ll}\text { Notes } & 159\end{array}$

References $\quad 207$

Index 225 


\section{Preface}

Middle-man (to Author): If you do not identify your composition a history, how then do we itemize it? The rank and file is entitled to know.

Author (to middle-man): Sir, I identify it a gesture. Sir, the rank and file is entitled to know.

Middle-man (to Author): There is no immediate demand for gestures. There is immediate demand for history. We are historical agents not free agents.

Author (to middle-man): Sir, I identify it a history. Sir, itemize it accordingly.

with apologies to G. V. Desani

Do we have either the imagination or the courage to say 'no' to empire?

William Appleman Williams ${ }^{1}$

In an essay on 'The Location of Brazil', Salman Rushdie urges us to 'Play. Invent the World.' He continues:

The power of the playful imagination to change for ever our perceptions of how things are has been demonstrated by everyone from Laurence Sterne, in Tristram Shandy, to a certain Monty Python in his Flying Circus. Our sense of the modern world is as much the creation of Kafka, with his unexplained trials and unapproachable castles and giant bugs, as it is of Freud, Marx or Einstein.

But there lies in this playfulness a terrible danger, what many in academe have labelled nihilism, and of which Rushdie also seems quite aware:

This danger is whimsy. When there are no rules except the ones you make up, don't things get too easy? When pigs can fly, do they remain pigs, and if not, why should we care about them? Can a work of art grow into anything of value if it has no roots in observable reality? ${ }^{2}$

Two responses to this predicament are possible, according to Rushdie. The first is to be found in the work of artists who "put down 
roots within the world of dreams, the logic of whose work is the logic of the dreaming and not the waking mind'. The second is to be found in synthesizing (as Terry Gilliam, an American living in Britain, does) what Rushdie sees as the two strands of comedy, British and American: 'American comedy begins with the question, "Isn't it funny that ...?" whereas British comedy's starting point is the question, "Wouldn't it be funny if ...?"' Kafka, neither British nor American, utilized both. In part, Rushdie continues, Metamorphosis is premised on the question,

wouldn't it be funny if Gregor Samsa woke up one morning to find himself metamorphosed into a giant insect? But in fact it derives its (very black) humour from a rather more serious question: Isn't it funny that a man's family reacts with fear, embarrassment, shame, love, boredom and relief when the son of the house becomes something they do not understand, suffers terribly and finally dies?

Rushdie then proceeds to locate Brazil in the Kafka synthetic tradition, enabling Terry Gilliam to avoid the trap of whimsy.

Further, Rushdie informs us, Brazil is also about America. 'America bombards you with dreams and deprives you of your own' (p. 124), Rushdie quotes Gilliam, clearly limiting people in America to the synthetic tradition - in their response to the danger of whimsy. Isn't it funny that people are bombarded with dreams in the land of the free and cannot articulate their own? Wouldn't it be funny if that weren't the case?

Inside Out, Outside In is about the historical manifestation of Brazil and a few preliminary attempts to reforge a dreamworld outside and inside the practice of history. A few questions to begin: Isn't it funny that the most developed and professionalized academics in the world are also the most constricted by their absorption with questions of methodology and proper rules of practice; and that their fantasy world of Nations, States, Classes, Races, Sexes, Agents, is structured so as to cement dynamic people in columns of transhistorical meaning? Wouldn't it be funny if one could use comparative history to undermine the foundation of these columns? Isn't it funny, to continue with this motif, that comparative history only seems to have supplied extra layers of cement? Wouldn't it be funny if we were to consider why that is so and begin the process of toppling these columns-cum-historiographical-bunkers?

And as we begin to consider comparative history it becomes 
obvious immediately that migrancy has an important role to play, particularly in the process of interrogating nationalist historiographies and the comparative histories founded on them. Rushdie has more to offer us here, too. He writes:

The effect of mass migrations has been the creation of radically new types of human being: people who root themselves in ideas rather than places, in memories as much as in material things; people who have been obliged to define themselves - because they are so defined by others - by their otherness; people in whose deepest selves strange fusions occur, unprecedented unions between what they were and where they find themselves. The migrant suspects reality: having experienced several ways of being, he understands their illusory nature. To see things plainly, you have to cross a frontier.

(pp. 124-5)

I am a migrant, born in London and living in the United States, and would welcome the opportunity to privilege my positions, my perspectives. And one way to do so, obviously, is to invoke Rushdie here and proclaim myself a representative of the condition of migrancy. Clearly, this alone is inadequate. It would be a mistake to extoll Rushdie's and Gilliam's own positions as migrants who are able to transcend the pitfalls of nationalism and patriotism. If things were that simple then Brazil, as America, would not exist at all to be lampooned or revealed in dark satire. America, after all, is the land of migrants - the 'uprooted', the 'transplanted', whatever. By such logic it should be the one country that is able to transcend Brazil. But the need for Caesar's columns, it would appear, seems more urgent when migration is increased. Perhaps in the babble of so many dreams, there is a yearning for conformity or simplicity, for a Whale to swallow all and provide order. ${ }^{3}$

There is a danger, then, one that Rushdie recognizes elsewhere, in assuming that migrancy necessarily differs from other forms of existence - that somehow crossing geographic boundaries is required before dreaming can begin. For we are all migrants, at least once we recognize that we go through stages in life, that educational boundaries as well as geographic ones are there to be crossed, with or without diplomas and passports. Here it is only necessary to describe the condition of many of Rushdie's women characters in The Moor's Last Sigh to make the point. Some of them do not travel far, but they all proclaim their migrancy - whether from one religion to another, 
one family to another, or (as in Midnight's Children also) from an imperial system to the Indian nation state.

But if we are all migrants, how we manage such changes (or at least their psychological impact), how we control, limit and channel our dreams, will parallel the ways in which we attempt to control, limit and channel our own political aspirations. Brazil is, in effect, resident within the individual. As Rushdie points out, the ending of the movie proclaims 'the triumph of the imagination, the dream, over the shackles of actuality' (p. 121). And clearly, in many instances, no external torturer (or threat of death) is necessary to force us into conformity. More often than not, we will do the work that an external force would be powerless to achieve. And with that in mind, I offer this book as a contribution to history: I will itemize it accordingly. For, if I do not do so, if I silence myself, fearing that I might be categorized as 'no longer a historian' or 'not seriously conforming to historical methods and practice', as I have heard others described - I myself will do the work of censors.

Migrancy (physical/geographic or otherwise) can provide vantage points from which to critique historical practice. With regard to physical migration this is particularly so when that practice revolves around nationalism and the nation state. But, with or without such migration, we may all situate ourselves simultaneously inside a system looking out, and outside looking in, and gain sufficient distance and a confusion of messages ('perspective by incongruity') ${ }^{4}$ to allow for the questioning of nationalist and other paradigms. Such questioning is almost of necessity unsettling. We do not want to undertake it for long, because it seems to be a project of dismantling without much building going on in its place. This is certainly the warning label that accompanies each postgraduate degree. ${ }^{5}$ Too close an inspection will ruin the eyes, or will cause early despair. It won't get you a job. Don't do it.

But are the dangers as severe as the health warnings suggest? It is difficult to tell. From inside the belly of the beast, the 'academic machine', we cannot see whether the dangers on its outside are more formidable than those we face already. And if we suspend the answer to such a question for the moment, it seems that one of the reasons we wish to remain where we are, tied to categories of class and country, is that doing so affords us privileges we do not wish to lose, however much we like to believe we are railing against the system. And after a period of complacency, lodging within the walls of mortgage and mutual fund, we are no longer able to see outside; we no longer need the warning label; we are of the system. 
In this book, I make a preliminary effort to suspend myself where Ian Dury would have us all, 'in-between'. Inside Out, Outside In attempts to take the familiar and provide alternate readings for it, using comparative history as its terrain. I suggest new approaches to comparative history and endeavor to make new connections to help free us from the sometimes limiting terrain of History. Wouldn't it be funny, I ask, if E. P. Thompson's father were a historian of British India? if Populists were implicated in Manifest Destiny? if we could allow it to be considered significant that Fidel Castro played a role in bringing about the end of apartheid in South Africa? if the man who introduced notions of self-determination to the world stage was also a prime mover behind the movie The Birth of a Nation? if history were not just mythology and propaganda, but more akin to complicated, funny and oh-so-dismal novels like The Moor's Last Sigh or A Son of the Circus? Of course, not all these questions can be considered here, some will have to be returned to at another time, but these are some of the questions that are there to be tackled - there are so many more worthy of, well, consideration.

I have incurred many debts along the way, and have learned a great deal from many people, some of whom would disagree with a lot of what I have written in the pages that follow. 'That's life,' as they say in France. I am hoping, however, that even where this may be the case the following people will accept my gratitude for their indirect contributions to my endeavor, and for the inspiring work they have done in their own right: Jim Baumohl, Lee Cassanelli, Laurence Dickey, Bob Engs, Gary Gerstle, Andy Gregg, Jamie Gregg, Evelyn Brooks Higginbotham, Shan Holt, Amy Kaplan, Philippa Levine, Walter Licht, and Liz Lunbeck. Among those who might be added to the above group are several others who have provided considerable feedback on various chapters. I am very grateful to Antoinette Burton (the most thorough and generous reader I have ever encountered), Rick Halpern (who made it possible for me to develop some of my ideas in papers I wrote for conferences he organized), Alan Cobley, Pramod Kale, Pratima Kale, David Ludden, Shula Marks, Carl Nightingale, Gyan Prakash, Dan Rodgers, Susan Thorne, and Mike Zuckerman.

My greatest debt is to Madhavi Kale, whose own departure from American History in graduate school and whose questioning of historical narratives about slavery and freedom forced me to reconsider most of what, under my own steam, I had come to believe 
about American history and history generally. I am still learning from our wonderful kids, Nikhil and Nadia, and can't wait to learn some more.

This work is dedicated to Owen Dudley Edwards, a scholar whose vast knowledge, expansive vision, and humor have always been in the back of my mind as I write and teach. 